Western University

Scholarship@Western

Brain and Mind Institute Researchers'

Publications

$1-1-2015$

\title{
Prolonged In Vivo Retention of a Cathepsin D Targeted Optical Contrast Agent in a Mouse Model of Alzheimer's Disease.
}

Jonatan A Snir

Mojmir Suchy

Keith St Lawrence

Robert H E Hudson

Stephen H Pasternak

See next page for additional authors

Follow this and additional works at: https://ir.lib.uwo.ca/brainpub

Part of the Neurosciences Commons, and the Psychology Commons

Citation of this paper:

Snir, Jonatan A; Suchy, Mojmir; Lawrence, Keith St; Hudson, Robert H E; Pasternak, Stephen H; and Bartha, Robert, "Prolonged In Vivo Retention of a Cathepsin D Targeted Optical Contrast Agent in a Mouse Model of Alzheimer's Disease." (2015). Brain and Mind Institute Researchers' Publications. 69.

https://ir.lib.uwo.ca/brainpub/69 


\section{Authors}

Jonatan A Snir, Mojmir Suchy, Keith St Lawrence, Robert H E Hudson, Stephen H Pasternak, and Robert Bartha 


\title{
Prolonged In Vivo Retention of a Cathepsin D Targeted Optical Contrast Agent in a Mouse Model of Alzheimer's Disease
}

\author{
Jonatan A. Snir ${ }^{\mathrm{a}, \mathrm{b}}$, Mojmir Suchy ${ }^{\mathrm{b}, \mathrm{c}}$, Keith St. Lawrence ${ }^{\mathrm{a}, \mathrm{d}}$, Robert H.E. Hudson ${ }^{\mathrm{c}}$, \\ Stephen H. Pasternak ${ }^{\mathrm{e}, \mathrm{f}}$ and Robert Bartha ${ }^{\mathrm{a}, \mathrm{b}, *}$ \\ ${ }^{a}$ Department of Medical Biophysics, University of Western Ontario, London, Ontario, Canada \\ ${ }^{\mathrm{b}}$ Centre for Functional and Metabolic Mapping, Robarts Research Institute, University of Western Ontario, London, \\ Ontario, Canada \\ ${ }^{\mathrm{c}}$ Department of Chemistry, University of Western Ontario, London, Ontario, Canada \\ ${ }^{\mathrm{d}}$ Medical Imaging, Lawson Health Research Institute, London, Ontario, Canada \\ e J. Allyn Taylor Centre for Cell Biology, Molecular Brain Research Group, Robarts Research Institute, \\ University of Western Ontario, London, Ontario, Canada \\ ${ }^{\mathrm{f}}$ Department of Clinical Neurological Sciences, Schulich School of Medicine, University of Western Ontario, \\ London, Ontario, Canada
}

Accepted 26 May 2015

\begin{abstract}
.
Background: Cathepsin D (CatD) is a lysosomal protease that is elevated early in Alzheimer's disease (AD). We have previously developed a Targeted contrast agent (CA) to detect CatD activity in vivo, consisting of a magnetic resonance imaging/fluorescent moiety linked to a cell penetrating peptide (CPP) by means of a CatD cleavage site and have demonstrated its uptake in the brain of an AD mouse model.

Objective: The purpose of this study was to characterize the in vivo retention of a near infra-red fluorescent dye labeled version of this CA.

Methods: Six adult C57B1/6 wild-type mice and six adult 5XFAD transgenic AD mice were studied using a small animal imaging system at five and twelve months of age using our novel Targeted CA, or two different control CAs; a Non-Targeted (lacking the CatD cleavage site) and a Non-Penetrating (lacking the CPP). Following intravenous CA administration, the optical signal was recorded within the brain and uptake and washout curves were measured and fitted to a one-phase exponential decay curve.

Results: In all wild-type and 5XFAD mice, the washout of the Targeted CA that included a CPP domain was significantly slower than the washout of the Non-Penetrating and Non-Targeted CA. Furthermore, the washout of the CatD Targeted CA was significantly slower in the 5XFAD mice compared to the age matched wild-type controls $(p<0.05)$ at 5 and 12 months of age. Control CAs showed no differences in washout.

Conclusions: The prolonged retention of the CatD targeted CA in 5XFAD mice suggests this agent may be useful for AD detection.
\end{abstract}

Keywords: Alzheimer's disease, Cathepsin D, molecular imaging, optical imaging, transgenic mice

\section{INTRODUCTION}

\footnotetext{
*Correspondence to: Robert Bartha, PhD, Centre for Functional and Metabolic Mapping, Robarts Research Institute, 100 Perth Drive, London, Ontario, N6A 5K8, Canada. Tel.: +1 $5196635777 /$ Ext. 24039; Fax: +1 519931 5224; E-mail: rbartha@ robarts.ca.
}

An estimated 115 million people will have dementia by 2050 worldwide with Alzheimer's disease (AD) being the most common cause [1]. The first description of AD over a century ago highlighted neurofibrillary 
tangle (NFT) and amyloid plaque accumulation [2] as two pathological changes associated with the disease. These have remained central to the postmortem confirmation and definitive diagnosis of $\mathrm{AD}$ to this day; however, the development of AD involves many subcellular and morphological features associated with loss of synapses [3], mitochondrial dysfunction and oxidative stress [4], and neurovasculature disruption $[5,6]$. Currently, diagnosis of AD is based upon clinical assessment, and although biomarkers have been proposed, these are not uniformly recommended for clinical use. This problem has taken on urgency, as several promising clinical trials may have failed, because treatment was initiated too late in the disease, when irreversible synaptic and neuronal loss had already occurred [7-11].

The development of imaging biomarkers provides a means to non-invasively detect brain changes associated with $\mathrm{AD}$ to monitor disease progression and the effects of treatment. Imaging biomarkers include brain structural changes [12], blood flow [13, 14], function [15], and glucose utilization [16, 17]. Recently, positron emission tomography (PET) imaging with the ${ }^{11} \mathrm{C}$-labelled Pittsburgh compound B, or PiB [18] has provided insight into the accumulation of amyloid pathology in the brain. PiB binding correlates with cerebral atrophy [19], it inversely correlates with cerebral glucose metabolism [20], and it strongly relates to the degree of memory impairment [21]. However, some studies have also shown PiB uptake in a significant proportion of non-demented elderly controls [22]. Moreover, many anti-amyloid treatments have failed in clinical trials and therefore interest in NFT pathology has intensified [23]. Imaging this biomarker, an aggregate of hyperphosphorylated tau protein, could provide important information about the course of the disease [24]. Novel ligands targeting NFT have shown promise in murine models of $\mathrm{AD}[25,26]$ and more recently in humans [27, 28]. Currently, however, the aforementioned biomarkers are hampered by variability and are frequently positive in normal older patients [7, 23, 29] sometimes more than 15 years before clinical symptoms [30].

One possible novel biomarker for AD is Cathepsin D (CatD). CatD is a lysosomal aspartic endopeptidase (EC 3.4.23.5) involved in normal protein turnover associated with tissue homeostasis including tissue renewal, remodeling, and regulation of aging and programmed cell death [31]. However, CatD is elevated within brain parenchyma and the cerebrospinal fluid of $\mathrm{AD}$ patients and active $\mathrm{CatD}$ is present at high levels in amyloid plaques [32-34]. In addition, increased expression of CatD has been proposed to be the earliest histopathological feature of AD [33]. Therefore, there is increasing interest in developing molecular imaging techniques targeting CatD for the early diagnosis of $\mathrm{AD}$ [35].

Animal models provide a consistent platform for testing early diagnostic techniques and can provide insight into the etiology and pathophysiology of human neurodegenerative diseases [36]. Transgenic ( $\mathrm{Tg}$ ) mice are the most common model of $\mathrm{AD}$, while very few rat [37], and even fewer non-human primate models exist [37-39]. Although many different Tg mouse strains are available, the 5XFAD model [40] has several key features requisite for $\mathrm{AD}$ modeling. These mice rapidly accumulate cerebral pathogenic amyloid protein $(A \beta)$ that begins at two months and reaches a very large burden by nine months. They are also characterized by hippocampal synaptic dysfunction as early as six months [41], and impaired memory as well as neuronal loss and synaptic degeneration by nine months that worsens by 12 months [40]. Furthermore, previous work using this strain showed co-localization of the CatD enzyme with intra-lysosomal $A \beta$ aggregates at one month of age [42] and increased CatD expression compared to non-Tg controls at 3.5 months [43]. The latter suggests that this strain is an appropriate platform for investigating contrast agents (CA) targeting CatD.

The passage of molecules from the circulation across the blood-brain barrier (BBB) into the brain is highly selective, making drug delivery difficult [44-47]. Most CAs do not normally cross the BBB unless it is damaged. One strategy to deliver contrast agents into the brain is to use cell penetrating peptides (CPP) [48]. One CPP is derived from Tat peptide (YGRKKRRQRRR) of the HIV-1 virus, which allows transport both into and out of the brain [48]. This CPP has been explored for drug delivery [49] as well as cellular delivery of CAs [50]. It is believed that hydrophilic arginine-rich CPPs such as HIV-1 Tat may be transported across membranes by direct penetration at high concentrations [51], and by endocytosis at lower concentrations [52], although there is no consensus on the mechanism of uptake and maintenance of functionality of cargos after delivery [53].

We have previously described a dual modality (MRI and fluorescence) CatD targeted CA consisting of an imaging moiety conjugated to a peptide composed of a CatD cleavage site and a CPP $[54,55]$. The CPP allows transport across membranes bidirectionally. In regions 
with increased CatD activity, cleavage at the CatD site removes the CPP, causing prolonged retention of the imaging moiety. Because each CatD enzyme molecule can cleave many substrate CA molecules, this strategy potentially offers amplification compared to contrast agents that depend on target binding. We have shown that this CA is taken up preferentially by cultured cells overexpressing CatD [54]. In addition, it exhibited a distinct difference in uptake and retention over a $2 \mathrm{~h}$ period post administration in an APPswe, PSEN1dE9 Tg mouse model compared to wild-type (WT) mice in ex vivo studies [55]. In the current study, we have conjugated this agent with IRDye 800 , a near infrared (NIR) fluorescent dye that can be detected through several centimeters of tissue [56] and exhibits a much higher fluorescence than the commonly used NIR dye indocyanine green [57]. This fluorophore has increased stability in blood [58] and is non-toxic at doses up to $\sim 428 \mathrm{nmol}$ [59]. As little as $5 \mathrm{pmol}[58,60]$ of this dye is required for detection in rodents. This new agent is suited for in vivo, non-invasive optical imaging to examine CA washout kinetics following intravenous administration.

The objective of this study was to evaluate the uptake and washout kinetics of the newly modified CA in vivo in 5XFAD Tg AD and WT control mice using NIR optical imaging. We hypothesized that the agent would be preferentially retained in the brain of 5XFAD Tg mice compared to WT mice. To better understand the mechanism of uptake of this agent, we compared washout kinetics for three similar CAs in 12-month-old 5XFAD and WT mice: 1) a diagnostic CatD Targeted agent having an imaging moiety, a CatD cleavage site, and a CPP; 2) a control Non-Penetrating agent having an imaging moiety, an incomplete CatD cleavage site lacking the CPP; and 3) a control Non-Targeted agent having only an imaging moiety and a CPP but no CatD cleavage site. Here we show that the cell penetrating CatD Targeted CA is taken up and retained more efficiently in the brain than the Non-Penetrating and Non-Targeted agents, and that this agent can distinguish $\mathrm{AD}$ mice from WT mice at 5 months and 12 months of age.

\section{MATERIALS AND METHODS}

\section{CA synthesis and characterization}

The IRDye 800 from LI-COR Biosciences (Lincoln, NE, USA) was chosen for NIR detection (part of the detection probe along with the chelated $\mathrm{Gd}^{3+}$ lanthanide metal). Peptide sequences were assembled on a Wang resin using a standard solid phase peptide synthesis protocol [63]. Conjugation of DOTAderived terminal monomer and subsequent HPLC purification of peptides 1a-c was performed as previously described [54, 55] (Fig. 1). In separate reaction vessels (Falcon tubes) peptides 1a $(4.2 \mathrm{mg}$, $\left.1.2 \times 10^{-6} \mathrm{~mol}\right), \quad 1 \mathrm{~b}\left(0.7 \mathrm{mg}, 3.0 \times 10^{-7} \mathrm{~mol}\right)$, and 1c $\left(2.7 \mathrm{mg}, 1.5 \times 10^{-6} \mathrm{~mol}\right)$ were treated with the solution of IRDye $800 \mathrm{CW}$ maleimide $(2 ; 1.4 \mathrm{mg}$, $1.2 \times 10^{-6} \mathrm{~mol}$, peptide $1 \mathrm{a} ; 0.4 \mathrm{mg}, 3.0 \times 10^{-7} \mathrm{~mol}$, peptide $1 \mathrm{~b} ; 1.8 \mathrm{mg}, 1.5 \times 10^{-6} \mathrm{~mol}$, peptide $\left.1 \mathrm{c}\right)$ in acetonitrile $(200 \mu \mathrm{L}$, peptide $1 \mathrm{a} ; 100 \mu \mathrm{L}$, peptide $1 \mathrm{~b}$; $400 \mu \mathrm{L}$, peptide $1 \mathrm{c})$ and water $(1 \mathrm{~mL}$, peptide $1 \mathrm{a}$; $400 \mu \mathrm{L}$, peptide $1 \mathrm{~b} ; 1.6 \mathrm{~mL}$, peptide $1 \mathrm{c})$. The tubes were set aside for $48 \mathrm{~h}$ at room temperature in the dark (wrapped in $\mathrm{Al}$ foil). The solvents were removed by lyophilization, the residues were dissolved in acetonitrile $(200 \mu \mathrm{L}$, peptide $1 \mathrm{a} ; 50 \mu \mathrm{L}$, peptide $1 \mathrm{~b}$; $300 \mu \mathrm{L}$, peptide $1 \mathrm{c})$ and water $(1 \mathrm{~mL}$, peptide $1 \mathrm{a}$; $100 \mu \mathrm{L}$, peptide $1 \mathrm{~b} ; 300 \mu \mathrm{L}$, peptide $1 \mathrm{c})$ and $0.1 \mathrm{M}$ solution of $\mathrm{GdCl}_{3} \cdot 6 \mathrm{H}_{2} \mathrm{O}\left(38 \mu \mathrm{L}, 3.8 \times 10^{-6} \mathrm{~mol}\right.$, peptide $1 \mathrm{a} ; 10 \mu \mathrm{L}, 1.0 \times 10^{-6} \mathrm{~mol}$, peptide $1 \mathrm{~b} ; 30 \mu \mathrm{L}$, $3.0 \times 10^{-6} \mathrm{~mol}$, peptide $1 \mathrm{c}$ ) was added. The tubes were set aside for another $48 \mathrm{~h}$ at room temperature in the dark (wrapped in $\mathrm{Al}$ foil). The solvents were removed by lyophilization, the residues were dissolved in water and were purified by dialysis (for 5 days) using a membrane with a molecular weight cut-off of $500 \mathrm{Da}$. The solutions were lyophilized to produce the desired peptides 3a-c as green solids. The conjugates were characterized by high resolution electrospray ionisation mass spectroscopy (HR-ESI-MS) as follows:

Conjugate 3a (1.9 mg, 35\%), HRMS (ESI) $\mathrm{m} / \mathrm{z}$ : found $4512.0560[\mathrm{M}-2 \mathrm{H}]^{+}$(4512.0456 calculated for $\left.\mathrm{C}_{194} \mathrm{H}_{299} \mathrm{~N}_{56} \mathrm{O}_{49} \mathrm{~S}_{5} \mathrm{Gd}\right)$.

Conjugate $3 \mathrm{~b}(0.9 \mathrm{mg}, 90 \%)$, HRMS (ESI) $\mathrm{m} / \mathrm{z}$ : found $3387.3570[\mathrm{M}-2 \mathrm{H}]^{+}$(3387.3615 calculated for $\mathrm{C}_{137} \mathrm{H}_{210} \mathrm{~N}_{42} \mathrm{O}_{39} \mathrm{~S}_{5} \mathrm{Gd}$ ).

Conjugate 3c (4.2 mg, 78\%), HRMS (ESI) $\mathrm{m} / \mathrm{z}$ : found 2584.8555 (formic acid adduct) $[\mathrm{M}-2 \mathrm{H}]^{+}$ (2584.8543 calculated for $\mathrm{C}_{110} \mathrm{H}_{152} \mathrm{~N}_{18} \mathrm{O}_{34} \mathrm{~S}_{5} \mathrm{Gd}$ ).

The three conjugates were named according to their functional characteristics: Conjugate 3a (Fig. 1) was dubbed the CatD Targeted or diagnostic CA (having a CatD cleavage site and a CPP), conjugate $3 \mathrm{~b}$ (Fig. 1) was dubbed the Non-Targeted CA (having only a CPP), and conjugate $3 \mathrm{c}$ (Fig. 1) was dubbed the NonPenetrating CA (having only a partial CatD cleavage site, similar to what remains following cleavage by an active CatD enzyme). 

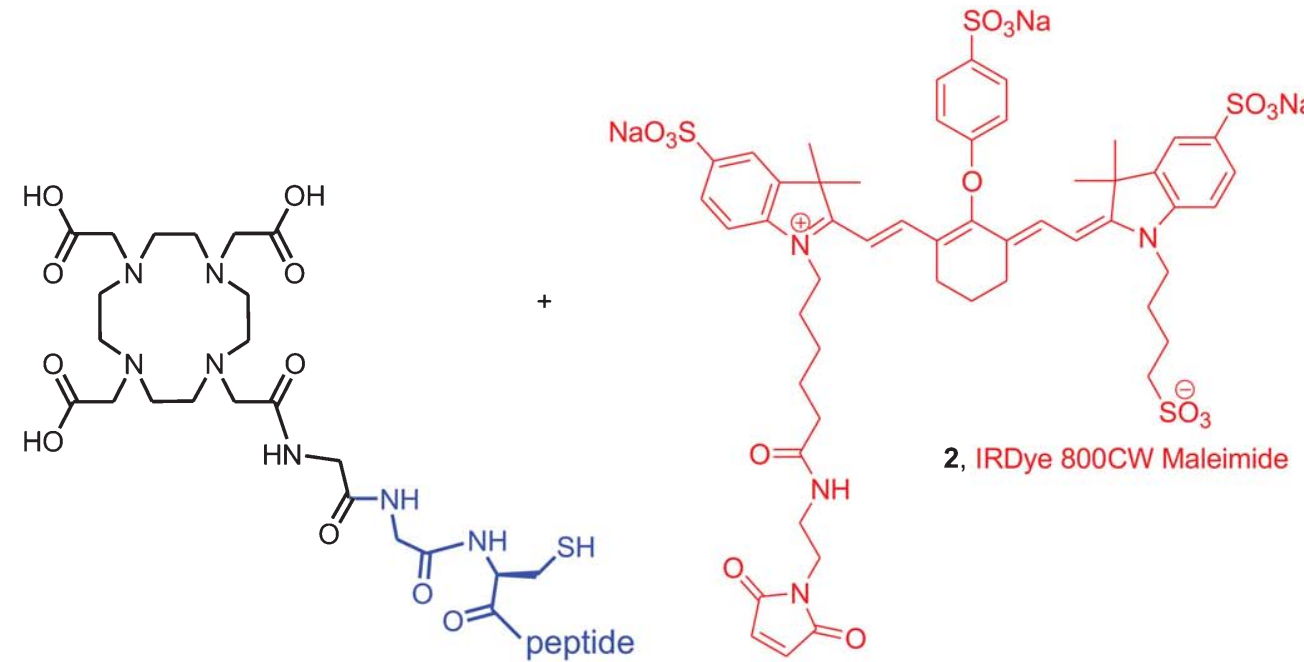

1a , peptide = GKP-ILF-FRL-YGR-KKR-RQR-RR = Cat-D targeted and penetrating peptide

1b, peptide $=$ YGR-KKR-RQR-RR

$=$ non-targeted peptide

$=$ non-penetrating peptide

1c, peptide $=$ GKP-ILF

i, $\mathrm{MeCN} / \mathrm{H}_{2} \mathrm{O}$

ii, $\mathrm{GdCl}_{3} \cdot 6 \mathrm{H}_{2} \mathrm{O}, \mathrm{MeCN} / \mathrm{H}_{2} \mathrm{O}$

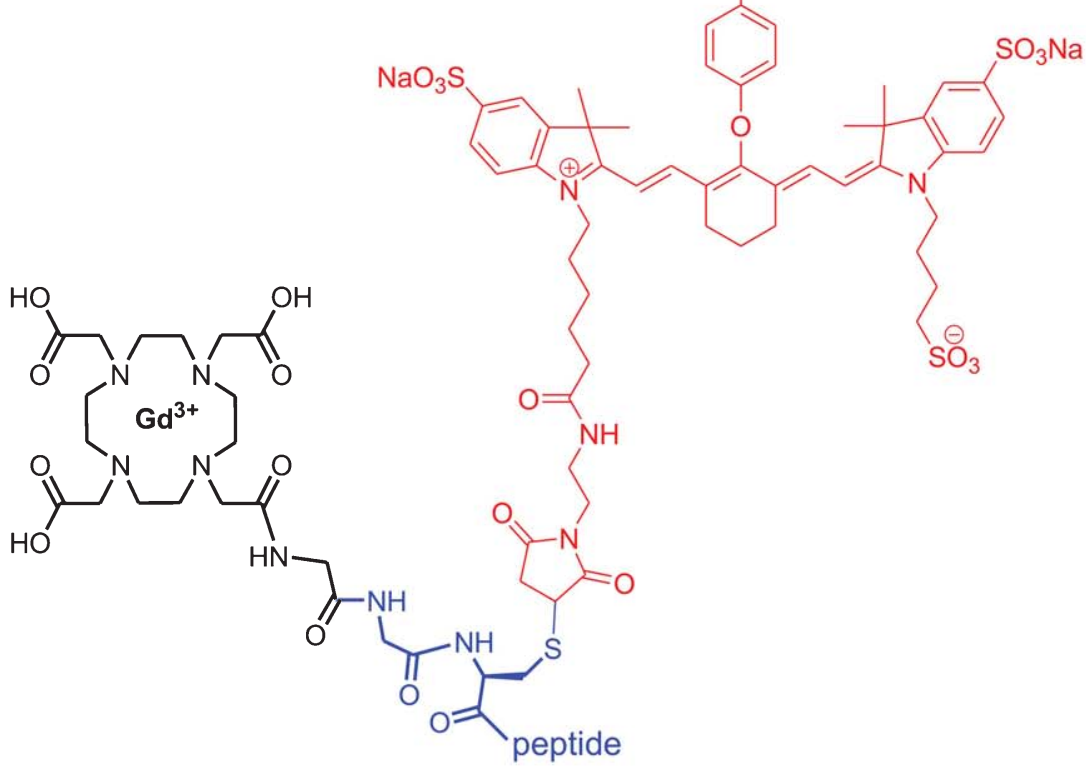

$\mathrm{NaO}_{3} \mathrm{~S}$

$\checkmark$

3a, peptide = GKP-ILF-FRL-YGR-KKR-RQR-RR = Cat-D targeted and penetrating peptide

3b, peptide $=$ YGR-KKR-RQR-RR

$=$ non-targeted peptide

3c, peptide $=$ GKP-ILF

$=$ non-penetrating peptide

Fig. 1. Synthesis of the different CAs. CatD Targeted (3a), Non-Targeted (3b), and Non-Penetrating (3c) conjugates used in this study.

\section{CA optical properties}

Optical properties were characterized using a SpectraMax M5 spectorphotometer plate reader (Molecular
Dynamics Devices, Sunnyvale, CA, USA). The optimal excitation wavelength of our CA was determined for emission at $845 \mathrm{~nm}$ using excitation between 600 to $820 \mathrm{~nm}$ (no cut-off filter, high precision reading, 
and $2 \mathrm{~nm}$ step size). The optimal emission wavelength was made at wavelengths ranging from 790 to $850 \mathrm{~nm}$ following excitation at $780 \mathrm{~nm}$. To control for backscatter and lamp light contamination, the purified milli-Q water fluorescence values were subtracted from all other measurements. Furthermore, to measure CA fluorescence following cleavage with the targeted enzyme (C3138-10UN; Sigma-Aldrich Canada Co., Oakville, Ontario), $25 \mu \mathrm{M}$ solutions of either CatD targeted, non-penetrating, or non-targeted CA were maintained at $37^{\circ} \mathrm{C}$ and a low $\mathrm{pH}(\sim 4.5)$ to replicate in vivo lysosomal conditions. Six wells were used to test each CatD targeted CA but three wells also included the CatD enzyme $(0.7 \mu \mathrm{M})$ incubated with the CA for $\sim 30 \mathrm{~min}$. Additionally, the fluorescent signal from each sample was measured as a function of time using the eXplore Optix system (GE Healthcare, Milwaukee, WI, USA). The fluorescence signal was examined in both the eXplore Optix system and the SpectraMax M5 Molecular Devices plate reader by measuring the signal from $1.35,2.75,5.5$, and $11 \mu \mathrm{M}$ concentrations of the CA corresponding to $0.27,0.55,1.1$, and $2.2 \mathrm{nmol}$, respectively. These solutions were placed in a black solid Costar 96well plate (Corning Life Science, Tewksbury, MA, USA).

\section{Animals}

All animal studies were conducted in accordance with the guidelines of the Subcommittee on Animal Care at Western University, conformed to the Canadian Council on Animal Care guide for the care and use of laboratory animals as well as the ARRIVE guidelines. B6SJL-Tg (APPSwFlLon, PSEN1*M146L*L286V) 6799 Vas/Mmjax Tg mice, commonly known as the 5XFAD line Tg6799 of a C57Bl/6 and B6SJL hybrid background and age-matched WT C57B1/6 (both from Jackson Laboratories, Bar Harbor, ME, USA) were used for this study. The 5XFAD mice overexpress human APP (695) with the Swedish (K670N, M671L), Florida (I716V), and London (V717I) Familial Alzheimer's Disease (FAD) mutations and the human PS1 gene harboring two FAD mutations, namely, M146L and L286V [43].

There was no significant difference in average mouse weight (5XFAD: $23.1 \pm 1.6 \mathrm{~g}$; WT: $23.5 \pm 2.5 \mathrm{~g}$ ) between the groups at five months; however, at 12 months, the body weight of the 5XFAD mice $(23 \pm 1.5 \mathrm{~g})$ was significantly lower $(p<0.05)$ than the WT mice $(31 \pm 1.9 \mathrm{~g})$.

\section{Experimental design}

To examine whether the CatD Targeted diagnostic CA could be used to differentiate between old 5XFAD mice having progressive disease pathology and old yet healthy control mice, six $(n=6)$ 5XFAD and six $(n=6)$ age-matched WT $(\mathrm{C} 57 \mathrm{Bl} / 6)$ control mice were studied at 12 months of age. To determine whether observed differences could be attributed to the targeting and BBB penetrating moieties attached to the CA, the uptake and washout of the three different CA versions were compared. The ability of the CatD Targeted CA to differentiate between the 5XFAD and WT control mice at an earlier disease stage was also studied at five months of age.

\section{Optical imaging}

Animals were kept warm $\left(\sim 37^{\circ} \mathrm{C}\right)$ using a latex glove containing warm water placed over the lower back and extremities. The warm water was replaced every $10 \mathrm{~min}$. Two animals were scanned simultaneously using a Y-shape nose cone for isofluorane anesthesia with a scavenger system connected to a charcoal filter. Hair was removed from the scalp using an electric razor, and depilatory agent (e.g., Nair; Brookvale, Australia) prior to optical imaging. All mice received an intravenous injection of $5 \mathrm{nmol} \mathrm{CA}$ suspended in $200 \mu \mathrm{L}$ PBS through a tail catheter. One $(n=1)$ 5-month-old 5XFAD mouse received a subcutaneous (sc) injection in the flank to examine the time delay for peak fluorescent signal.

Optical imaging was performed using the eXplore Optix system (GE Healthcare, Milwaukee, WI, USA); a reflectance-based, raster scanning, time domain optical imaging system with a $3 \mathrm{~mm}$ source-detector distance. An $80 \mathrm{MHz}, 780 \mathrm{~nm}$ pulsed diode laser (picoQuant, Berlin, Germany) was employed with a $10 \mathrm{~nm}$ FWHM bandpass excitation filter centered at $780 \mathrm{~nm}$ (Thorlabs, Newton, NJ, USA). Light was collected with a $55 \mathrm{~nm}$ FWHM bandpass excitation filter centered at $845 \mathrm{~nm}$ (Chroma Technology Corp., Bellows Falls, VT, USA). The maximum power output of the laser at the surface of the sample or animal did not exceed $10 \mu \mathrm{W}$, and signal was collected with an integration time of $100 \mathrm{~ms}$ resulting in an image acquisition time of $\sim 2$ min. Images were acquired for a maximum duration of $4.5 \mathrm{~h}(270 \mathrm{~min})$, with a variable temporal step size depending on the magnitude of the observed signal changes. The horizontal level of heads of both animals was manually adjusted to be of equal distance to the detector. 


\section{Optical signal analysis}

All optical signal data were recorded as photon counts per second for each pixel. Optical signal maps were analyzed using Image J 1.46r (National Institutes of Health, USA). Statistical analysis was performed using Prism 5 (GraphPad Software, Inc., CA, USA). The average fluorescence signal (average pixel intensity \pm standard deviation) time course from within a selected region of interest (ROI) was used for analysis. Unless otherwise stated, the ROI was drawn around only the head region visualized under plain white light (WL). The baseline signal amplitude was centered at zero by subtracting the background signal measured prior to the injection of agent. To equalize the step sizes, a piecewise cubic Hermite interpolation was applied to the data and binned into 1-min intervals using MATLAB (The MathWorks, Inc., Natick, MA, USA). For all parameters excluding the absolute peak enhancement values, the CA signal was normalized to the maximum intensity. The CA washout following maximum peak enhancement was modeled and fitted using a least squares minimization method in Prism. The model function incorporated a constant maximum enhancement period followed by a one phase exponential decay [Eq 1] to determine the washout coefficient $\left(\lambda_{\text {Total }}\right)$ and asymptote (Plateau Total $)$.

$$
Y(t)=\left\{\begin{array}{c}
Y_{0}, t<T_{0} \\
\text { Plateau }_{\text {Total }}+\left(Y_{0}-\text { Plateau }_{\text {Total }}\right) \\
e^{-\lambda_{\text {Total }}\left(t-T_{0}\right)}, t \geq T_{0}
\end{array}\right.
$$

The initial values of $Y_{0}$ (Y-intercept) were set to 1 because the data were normalized. $T_{0}$, the time delay from CA administration to washout was fitted by Prism to account for variability in the start time of observed CA washout, and the asymptote Plateau ${ }_{\text {Total }}$ was restricted to values greater than zero. The latter constraint is reasonable because the CA will not clear from the body completely within the scan time allotted for the current study, however, we observed the signal return to baseline levels $(n=2)$ within $24 \mathrm{~h}$; data not shown. For statistical purposes, the extra sum-of-squares F-test was used to compare the parameters $\lambda_{\text {Total }}$ and Platea $u_{\text {Total }}$ between groups with a $p$-value $<0.05$ required to achieve significance.

The time delay following maximum enhancement to signal washout $\left(T_{0}\right)$, the absolute maximum peak signal intensity value $\left(S I_{\max }\right)$, the linear slope $\left(S I_{2 h r s}-S I_{1 h r s}\right)$ between the signal at $1 \mathrm{~h}$ post injection $\left(S I_{1}\right)$ and the signal at $2 \mathrm{~h}\left(S I_{2}\right)$ post injection, and the attenuation coefficient for data collected during the first hour post peak enhancement $\left(\lambda_{1 h r}\right)$ assuming a plateau of zero were measured in each animal. Both $S I_{2 h r s}-S I_{1 h r s}$ and $\lambda_{l h r}$ were calculated to provide a straight-forward metric that could be easily applied in patients. A Student's $t$-test was used to compare parameters between the different groups with a $p$-value $<0.05$ required to achieve significance. Receiver Operating Characteristic (ROC) curve analysis was performed using the Prism built-in analysis tool with $95 \%$ confidence level to determine whether CA washout parameters $\left(T_{0}, \lambda_{1 h r}\right.$, and $\left.S I_{\max }\right)$ could differentiate between the AD model to WT control mice.

\section{CatD expression in brain tissue}

WT and 5XFAD mice (4 and 12 months old) were perfused with saline followed by $10 \%$ neutral buffered formalin (NBF). Brains were dissected and immersed in $10 \% \mathrm{NBF}$ for $24 \mathrm{~h}$, embedded in paraffin, and $5 \mu \mathrm{m}$ sections were cut. Antigen retrieval was performed using formic acid (70\%, 2 min) and sections were immunolabeled with antibody against CatD ( 1 : 200; C-20 sc-6486 from Santa Cruz Biotechnology; Santa Cruz, CA, USA). This antibody was detected using an anti-rabbit secondary antibody conjugated to horseradish peroxidase, prior to colorimetric detection using nickel 3,3'-diaminobenzidine (DAB; $0.15 \mathrm{mg} / \mathrm{ml}$ in $0.03 \% \mathrm{H}_{2} \mathrm{O}_{2}$; Sigma-Aldrich, Oakville, ON, Canada) with the Vectastain ABC kit (Dako, Burlington, ON, Canada) and counterstaining with Hematoxylin and Eosin (H\&E; Leica Microsystems Inc., Concord, ON, Canada). Sections were imaged and digitized using a TISSUEscope CF slide scanner (Huron Technologies, Waterloo, ON, Canada) at a $0.5 \mu \mathrm{m}$ resolution using bright field imaging (at $40 \mathrm{X})$. Staining area was measured in three regions (each covering $>200,000 \mu \mathrm{m}^{2}$ ) of primary somatosensory cortex in each of three sections per mouse, in each of three mice per group using ImageJ (v. 1.46r, http://rsbweb.nih.gov/ij/) with staining identified using the color deconvolution plugin written by Dr. Gabriel Landini (available via the aforementioned website) and quantified using the ImageJ built-in threshold tool.

\section{RESULTS}

\section{CA optical properties}

Measuring the fluorescence at $845 \mathrm{~nm}$, each CA had an excitation peak at $780 \mathrm{~nm}$ (similar to non- 

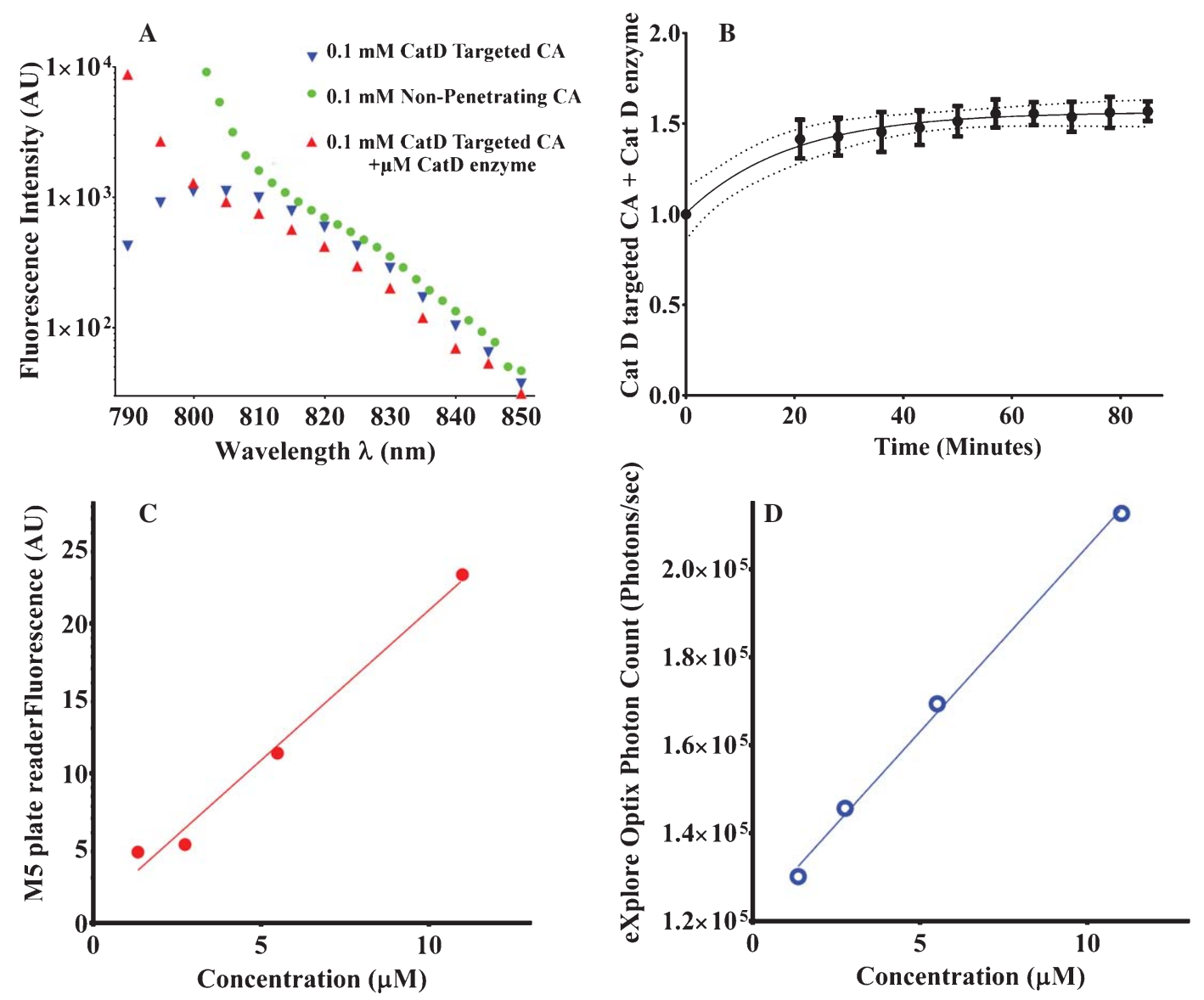

Fig. 2. Fluorescence characteristics of the CAs. A) Emission spectrum observed using the M5 plate reader at different wavelengths following excitation at $780 \mathrm{~nm}$ for the CatD Targeted CA (blue upside down triangles), the Non-Penetrating CA (green circles), and the CatD Targeted CA incubated with CatD (red triangles). The CatD Targeted agent has a peak width of about $15 \mathrm{~nm}$ (FWHM) centered at $\sim 805 \mathrm{~nm}$, whereas the Non-Penetrating agent has a peak emission centered below $790 \mathrm{~nm}$ (Not shown). B) Fluorescence characteristics of the CatD Targeted CA interaction with a CatD enzyme using the GE Optix eXplore optical scanner. The fluorescent signal intensity, normalized to the signal intensity prior to enzyme addition $(0.7 \mu \mathrm{M})$, increases to $\sim 1.5$ times the baseline level $1 \mathrm{~h}$ after incubation with the enzyme at $37^{\circ} \mathrm{C}$. The fluorescence measurements by both (C) M5 plate reader (red) and (D) eXplore optix (blue) for the same concentrations of CatD targeted CA in PBS are shown where regression lines for each set are plotted.

conjugated IRDye 800). We then measured the emission intensity spectrum for all three CA variants using an excitation laser at $780 \mathrm{~nm}$. The CatD Targeted (Fig. 2A, upside down blue triangles) and NonTargeted (data not shown) agents had a similar peak emission centered at $\sim 805 \mathrm{~nm}$. The Non-Penetrating CA (Fig. 2A, green circles), lacking the CPP, produced a higher peak at a slightly lower wavelength, which could not be fully measured because it overlapped with the excitation light source. The CatD Targeted CA incubated with the CatD enzyme (Fig. 2A, red triangles) produced an intermediate curve with significantly higher fluorescence than the intact, CatD Targeted
$\mathrm{CA}$ at wavelengths below $800 \mathrm{~nm}$. Furthermore, the Optix eXplore pre-clinical scanner measurements of the CatD Targeted CA after CatD enzyme addition showed a gradual increase in fluorescence over time, to about 1.5 times the original signal (Fig. 2B). The optical fluorescent signal changes detected using the M5 plate reader (Fig. 2C) were linear with CA concentration (ex/em $\left.780 / 845 \mathrm{~nm} ; \mathrm{R}^{2}=0.986\right)$ and correlated strongly (Pearson correlation $\mathrm{R}^{2}=0.97$; $p=0.01$ ) with the optical signal measured using the Optix eXplore pre-clinical scanner measurements (Fig. 2D) which were similarly linear with CA concentration $\left(\mathrm{R}^{2}=0.997\right)$. 


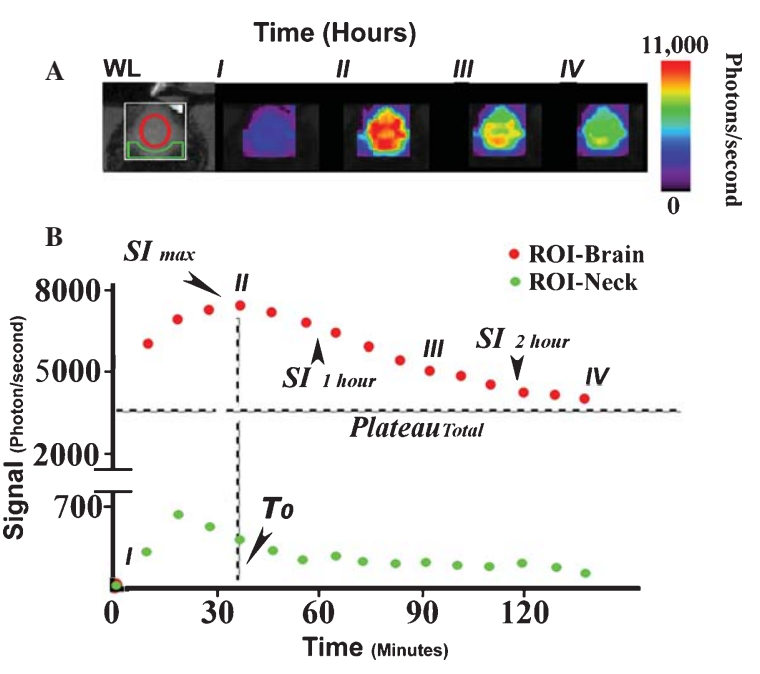

Fig. 3. Uptake and washout of the CatD targeted CA in a 5XFAD mouse. The NIR signal is collected over time from an ROI (white outline in A) with associated pseudo color bar indicating photons/second (A). The brain signal is then analyzed from an elliptical ROI (red outline in A; red data in B) drawn over the brain region and a control region closer to the neck (green outline in A; green data in B). Representative images of signal intensity are shown (left to right; I to IV) that correspond to epochs designated by the assigned letters on the NIR intensity curve (B). Analyzed variables include (some are indicated in $\mathrm{B}$ ): the time delay from $\mathrm{CA}$ administration to washout $\left(T_{0}\right)$, the peak signal intensity $\left(S I_{\max }\right)$, the exponential signal decay coefficient for the duration of each scan $\left(\lambda_{\text {Total }}\right)$, the signal value at asymptote $\left(\right.$ platea $\left._{\text {Total }}\right)$, the exponential signal decay coefficient for $1 \mathrm{~h}$ washout $\left(\lambda_{1 \mathrm{hr}}\right)$, the signal intensity at $1 \mathrm{~h}$ and $2 \mathrm{~h}$ after injection $\left(S I_{1}\right.$ and $S I_{2}$ respectively) and their associated signal decay rate $\left(S I_{2 h r s}-S I_{l h r s}\right)$.

\section{Optical signal dynamics}

An example of the NIR imaging data acquired on the GE eXplore Optix scanner is shown in Fig. 3. Following injection of the contrast agent, signal was acquired from the head (Fig. 3A; white rectangular ROI) to produce images. Signal changes from ROIs over the brain (Fig. 3A; red elliptical ROI) and from the skin and soft tissue over the neck (Fig. 3A; green ROI) were examined. Generally, optical signal increased rapidly following injection, reached a peak value, and then declined over time; a typical curve is shown in Fig. 3B. The signal from the skin/neck was more than 10 -fold lower than the signal from the brain region. More importantly, there were no significant differences observed in the uptake/washout kinetics of the CatD targeted CA between 5XFAD and WT mice in the skin/neck region (data not shown), therefore all subsequent analysis focus on the signal measured from the brain region only.
The key features of the uptake and washout curve include the time delay to signal washout $\left(T_{0}\right)$, the peak signal intensity $\left(S I_{\max }\right)$, the exponential signal decay coefficient for the entire scan period $\left(\lambda_{\text {Total }}\right)$ or $1 \mathrm{~h}$ washout $\left(\lambda_{1 h r}\right)$ starting at peak value, the asymptotic signal $\left(\right.$ Plateau $\left._{\text {Total }}\right)$, and lastly, the linear slope $\left(S I_{2 h r s}-S I_{1 h r s}\right)$ between the signal measured at $1 \mathrm{~h}$ and $2 \mathrm{~h}$ post injection. The measured characteristics of these curves are summarized in Table 1 for the 12-month-old mice and in Table 2 for the 5-month-old mice.

\section{Contrast agent pharmacokinetics in 12-month-old mice}

The pharmacokinetics of the different contrast agents were compared in 12-month-old WT mice (Fig. 4; Table 1). As expected, the signal from the Non-Penetrating CA (green curve, Fig. 4) peaked very quickly following injection $\left(T_{0}=14.1 \pm 2.3 \mathrm{~min} ; \lambda_{1 \mathrm{hr}}\right.$ $\left.=-1.42 \pm 0.14 \times 10^{-2} \mathrm{~min}^{-1}\right)$. The Non-Targeted CA (orange curve, Fig. 4) had a slightly longer $T_{0}(18.9 \pm 3.5 \mathrm{~min})$ with a $10 \%$ increase in signal at peak compared to initial measurements, and washed out more slowly $\left(\lambda_{1 h r}=-1.25 \pm 0.2 \times 10^{-2}\right.$ $\min ^{-1}$ ). Finally the CatD Targeted CA (blue curve, Fig. 4) exhibited the longest time delay to peak $\left(T_{0}=\right.$ $46.5 \pm 8.2 \mathrm{~min}$ ), and was cleared much more slowly $\left(\lambda_{1 h r}=-0.52 \pm 0.03 \times 10^{-2} \mathrm{~min}^{-1}\right)$ than the control CAs demonstrating the prolonged retention of the Targeted agent requires both the CPP and the CatD cleavage site.

The uptake and washout curves for each contrast agent were compared between 12-month-old WT and 5XFAD mice in Fig. 5, and the analysis of five different features is summarized for all groups in Table 1. Following injection of the Targeted CA, the uptake and washout curves of the 5XFAD and WT animals are clearly separated throughout the experiment (Fig. 5A). Although the CatD Targeted agent shows a trend to take longer to reach maximum signal intensity in 5XFAD mice $(72.2 \pm 43.8 \mathrm{~min})$ compared to controls $(46.5 \pm 8.2 \mathrm{~min})$, this difference was not statistically significant. The CatD Targeted agent reached a higher $\mathrm{SI}_{\max }$ in the $5 \mathrm{XFAD}$ mice $\left(7.1 \pm 0.8 \times 10^{3}\right.$ photons/s, Fig. $\left.5 \mathrm{~A}\right)$ compared to the WT mice $\left(4.6 \pm 0.5 \times 10^{3}\right.$ photons $\left./ \mathrm{s} ; p=0.019\right)$. The CatD Targeted agent washout coefficient fitted at $1 \mathrm{~h}$ $\left(\lambda_{1 h r}\right)$ for 5XFAD mice $\left(-0.28 \pm 0.08 \times 10^{-2} \mathrm{~min}^{-1}\right)$ was significantly different than for the WT controls $\left(-0.52 \pm 0.03 \times 10^{-2} \mathrm{~min}^{-1} ; p<0.05\right.$, Fig. 5B, Table 1) as was the washout parameter $\lambda_{\text {Total }}$ 


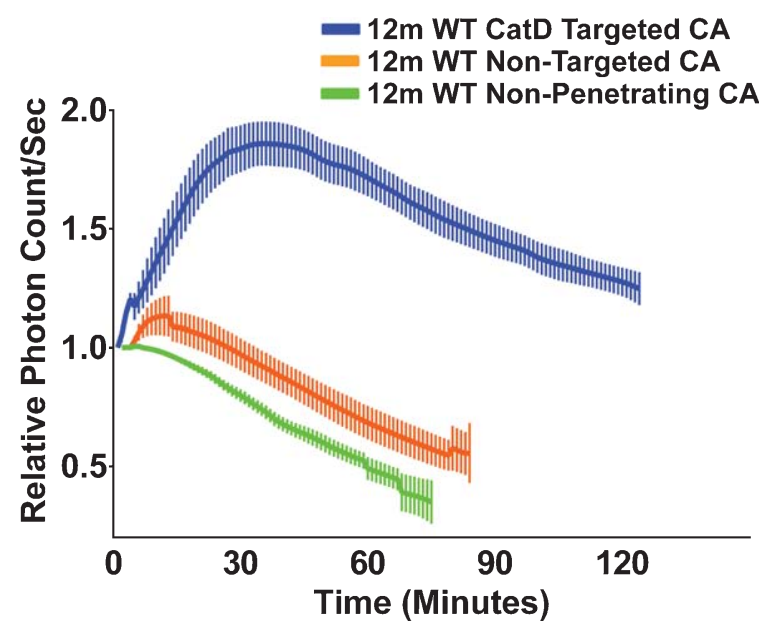

Fig. 4. CA mechanistic uptake and washout. Average optical imaging signal measurements for 12-month-old WT mice injected with either the Non-Penetrating CA, Non-Targeted CA, or CatD Targeted CA. Data were normalized to the first post CA administration measurement (mean \pm SEM).

$(-3.68 \pm 0.20$ versus $-0.68 \pm 0.03$ for 5 XFAD and control respectively; $p<0.01$, Fig. 5B, Table 1). In addition, the asymptote (Plateau Total $)$ was almost four times higher in the 5XFAD mice $(82 \pm 1 \%)$ compared to the control mice $(23 \pm 2 \%, p<0.01)$. Finally, there was a significant difference between $S I_{2 h r s}-S I_{1 h r s}$ $(-0.43 \pm 0.02$ versus $-0.15 \pm 0.08$ for 5 XFAD and control mice respectively (Table $1, p<0.01$ ) in 5XFAD mice and WT controls. Taken together, these results indicate that the contrast agent reached a significantly higher plateau in the 5XFAD mice compared to the WT mice and reached it faster.

To test whether the CatD targeted CA could differentiate between 5XFAD and WT mice, a ROC analysis was performed incorporating three different parameters $\left(T_{0}, \lambda_{1 h r}\right.$, and $\left.S I_{\max }\right)$ (null hypothesis: true area $=0.5$ ). For the 12-month-old 5XFAD compared to WT mice, the area under the curve (AUC) was $0.78(p=0.11), 0.81(p=0.07)$, and $0.86(p=0.04)$, for $T_{0}, \lambda_{1 \mathrm{hr}}$ and $S I_{\max }$, respectively.

\section{Non-Targeted and Non-Penetrating agents in 12-month-old mice}

When WT mice were injected with the NonTargeted CA, it took significantly longer for the signal to reach peak enhancement $\left(T_{0}\right)$ compared to the 5XFAD mice (Table $1, p<0.01$ ). However, there was no difference between groups in the time to peak for the Non-Penetrating agent. Most importantly, there were no significant differences between the parameters $\lambda_{\text {Total }}$, plateau $_{\text {Total }}$, and $\lambda_{1 h r}$ when comparing the 5XFAD and WT mice after administration of either the Non-Targeted (Fig. 5C) or Non-Penetrating (Fig. 5D) CAs (Table 1).

Table 1

Fluorescent signal intensity curve characteristics (average \pm standard error; $n=6$ ) in 12 months old 5XFAD and wild-type (WT) mice following different contrast agent $(\mathrm{CA})$ injections

\begin{tabular}{|c|c|c|c|c|c|c|}
\hline \multirow[b]{2}{*}{ Curve Characteristic } & \multicolumn{3}{|c|}{ WT } & \multicolumn{3}{|c|}{ 5XFAD } \\
\hline & Non-Penetrating & Non-Targeted & Cathepsin D Targeted & Non-Penetrating & Non-Targeted & Cathepsin D Targeted \\
\hline$T_{0}(\min )$ & $14.1 \pm 2.3^{\Psi \Psi}$ & $18.9 \pm 3.5 \S \S$ & $46.5 \pm 8.2 \S \S^{\Psi \Psi}$ & $11.4 \pm 2.8^{\alpha}$ & $9.8 \pm 4.1^{*}$ & $72.2 \pm 43.8 \S \S^{\Psi \Psi}$ \\
\hline$\lambda_{1 h r}\left(\times 10^{-2} \min ^{-1}\right)$ & $-1.42 \pm 0.15$ & $-1.25 \pm 0.18$ & $-0.52 \pm 0.03 \S \S^{\Psi \Psi}$ & $-1.42 \pm 0.13$ & $-1.28 \pm 0.20$ & $-0.28 \pm 0.08 * \S \S \Psi \Psi$ \\
\hline$\lambda_{\text {Total }}\left(\times 10^{-2} \min ^{-1}\right)$ & $-1.48 \pm 0.03^{\Psi}$ & $-1.15 \pm 0.07 \S$ & $-0.68 \pm 0.03 \oint \oint \Psi \Psi$ & $-1.33 \pm 0.27$ & $-1.23 \pm 0.45$ & $-3.68 \pm 0.20 * * \S \S \Psi \Psi$ \\
\hline Plateau $_{\text {Total }}(\%)$ & $0 \pm 2$ & $0 \pm 3$ & $23 \pm 2 \S \S \Psi \Psi$ & $1 \pm 1$ & 0 & $82 \pm 1 * * \S \S^{\Psi \Psi}$ \\
\hline$\underline{S I_{2 h r s}-S I_{1 h r s}\left(\times 10^{-2} \mathrm{~min}^{-1}\right)}$ & & & $-0.43 \pm 0.02$ & & & $-0.15 \pm 0.08^{* *}$ \\
\hline
\end{tabular}

${ }^{*}$ Significantly different from WT group (same CA) $p \leq 0.05 ;{ }^{* *} p \leq 0.01$. $\oint$ Significantly different from non-penetrating CA (same strain) $p \leq 0.05$; $\S \S p \leq 0.01 .{ }^{\Psi}$ Significantly different from non-targeted CA (same strain) $p \leq 0.05 ;{ }^{\Psi} p \leq 0.01 .{ }^{\alpha} n=2$.

Table 2

Fluorescent signal intensity curve characteristics (average \pm standard error; $n=6$ ) in 5 months old 5XFAD and wild-type (WT) mice following injections of the Cathepsin D targeted contrast agent (CA)

\begin{tabular}{lrr}
\hline Curve Characteristic & WT & CXFAD \\
\cline { 2 - 3 } & Cathepsin D Targeted & $64.1 \pm 25.8$ \\
\hline$T_{0}(\min )$ & $39.2 \pm 28.8$ & $-0.62 \pm 0.08^{*}$ \\
$\lambda_{1 h r}\left(\times 10^{-2} \min ^{-1}\right)$ & $-0.92 \pm 0.08$ & $-1.02 \pm 0.06^{* *}$ \\
$\lambda_{\text {Total }}\left(\times 10^{-2} \min ^{-1}\right)$ & $-1.25 \pm 0.03$ & $27 \pm 2$ \\
Plateau $_{\text {Total }}(\%)$ & $24 \pm 1$ & $-0.35 \pm 0.08$ \\
SI $_{\text {2hrs }}-S_{1 \text { hrs }}\left(\times 10^{-2} \mathrm{~min}^{-1}\right)$ & $-0.48 \pm 0.08$ & \\
\hline
\end{tabular}

* Significantly different from WT group (using CatD Targeted CA) $p \leq 0.05 ;{ }^{* *} p \leq 0.01$. 

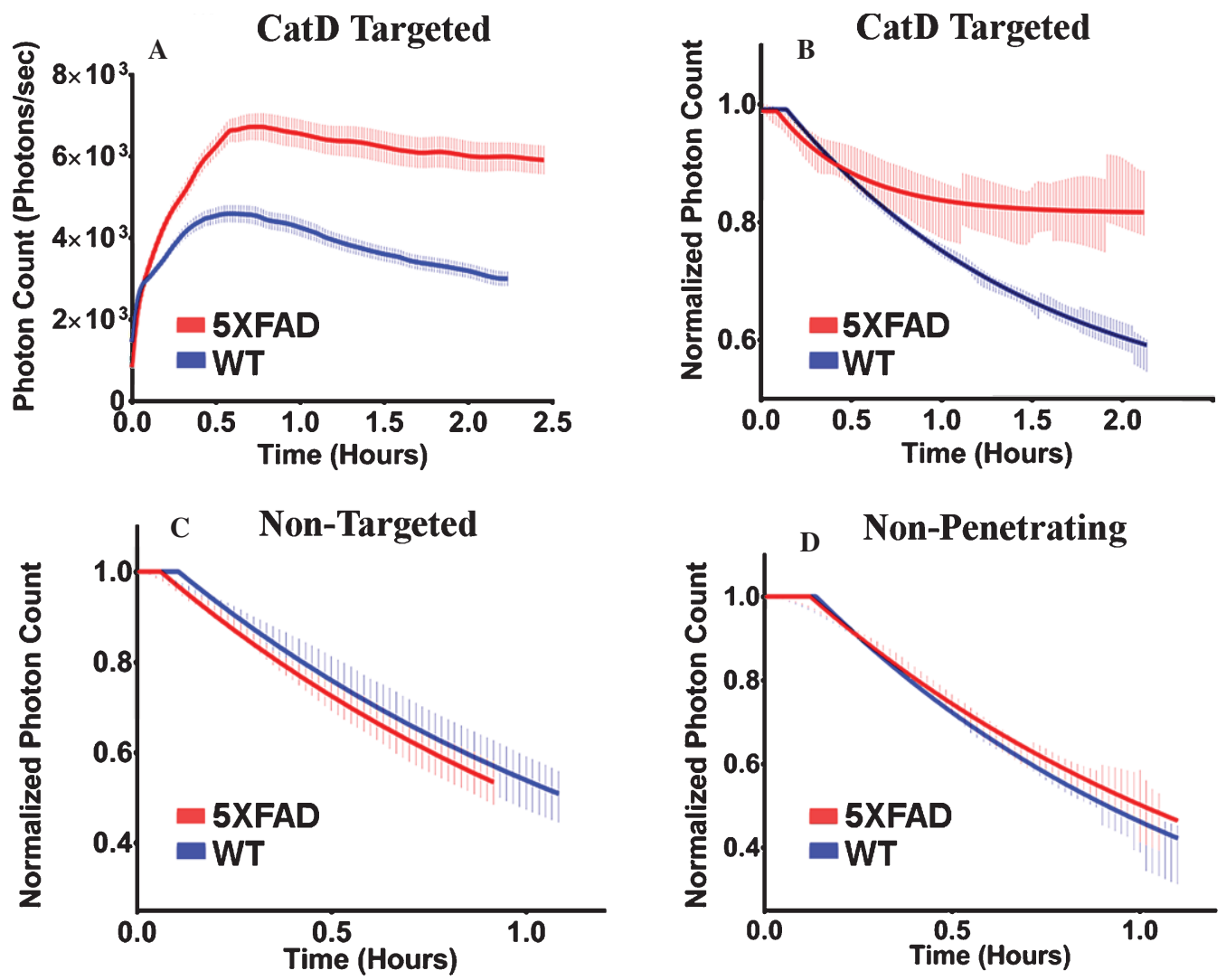

Fig. 5. Uptake and washout in 12-month-old WT and 5XFAD mice following CA administration. Non-normalized data for twelve month old mice injected with CatD Targeted CA (A; 5XFAD in red, WT in blue), normalized shifted data for 12-month-old mice injected with CatD Targeted CA (B; 5XFAD in red, WT in blue), mice injected with Non-Targeted CA (C; 5XFAD in red, WT in blue), and mice injected with Non-Penetrating CA (D; 5XFAD in red, WT in blue) are shown. Data are the mean \pm standard error of fluorescent signal as a function of time $(n=6)$
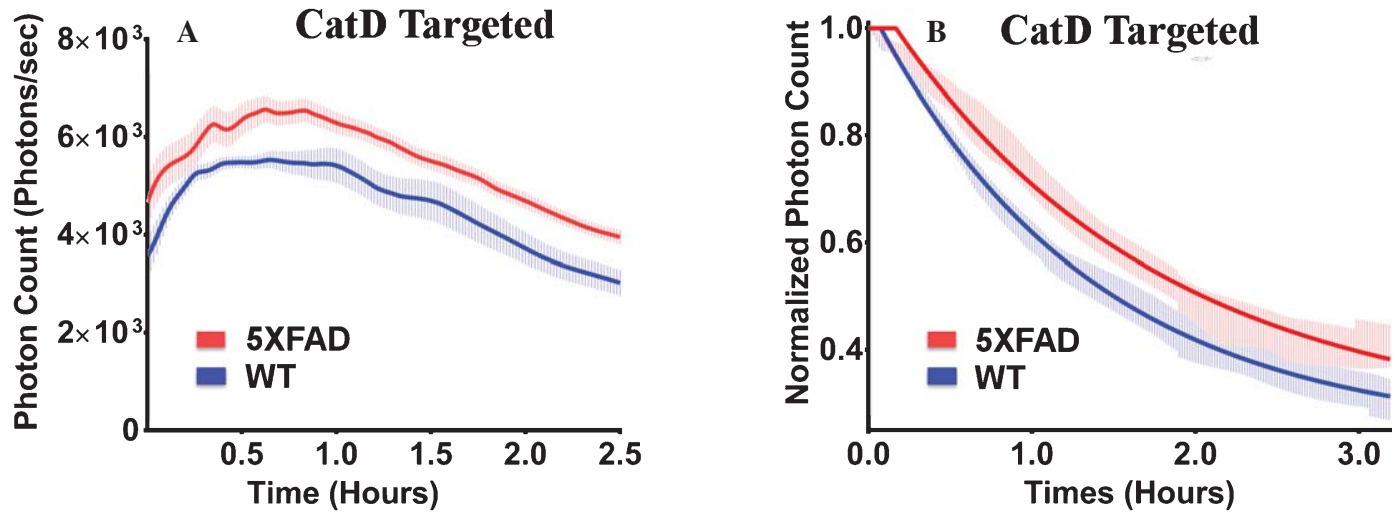

Fig. 6. CA washout in 5-month-old WT and 5XFAD mice following CatD Targeted CA administration. Non-normalized data for 5-month-old mice injected with CatD Targeted CA (A; 5XFAD in red, WT in blue, $n=5$ ), normalized shifted data for 12-month-old mice injected with CatD Targeted CA (B; 5XFAD in red, WT in blue, $n=6)$, data shown is mean \pm standard error of fluorescent signal as a function of time. 

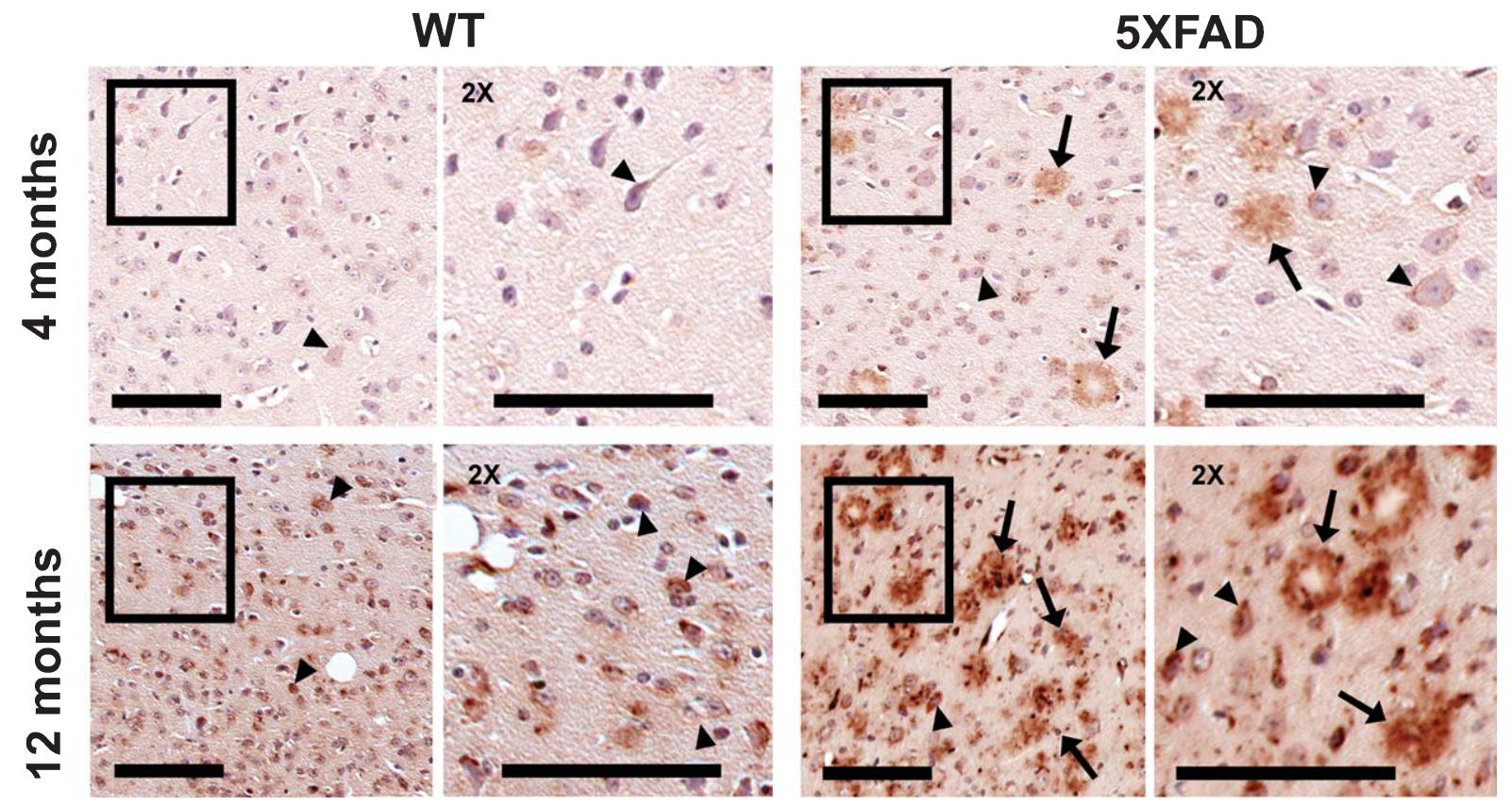

Fig. 7. Immunohistochemistry of CatD in WT and 5XFAD mice at 4 and 12 months of age. Photomicrographs of the cortex in mice showing CatD staining (brown) with Hematoxylin counter staining of the nuclei (blue). Enlarged views $(\times 2)$ show the vicinity near the black framed rectangles. CatD staining is present intracellularly (e.g., arrow heads) and in amyloid plaques (e.g., arrows). Scale bar $100 \mu \mathrm{m}$.

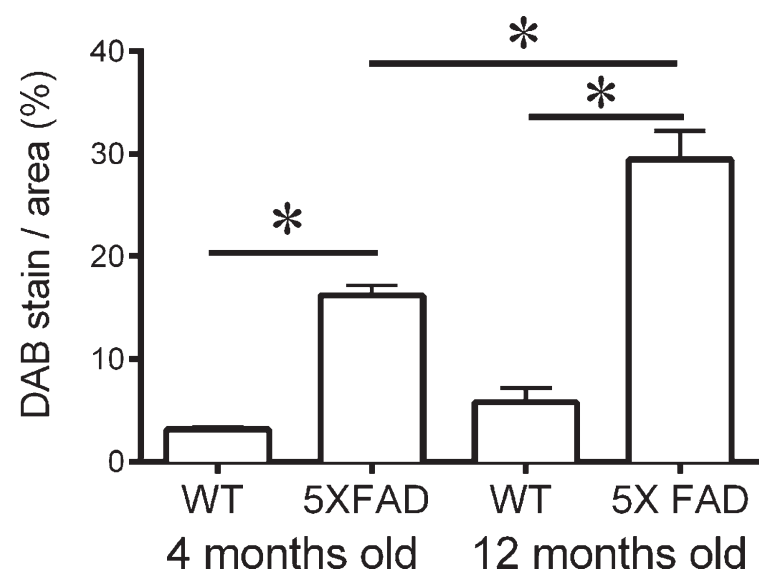

Fig. 8. Quantification of CatD-specific DAB staining. The area covered by CatD staining shown in Fig. 7 was quantitated using ImageJ software (mean \pm standard error of the mean; $n=3$ ). Significant differences are noted with an asterisk for $p \leq 0.01$.

\section{Contrast agent pharmacokinetics in 5-month-old mice}

The uptake and washout of the CatD Targeted CA is shown in both 5-month-old 5XFAD and WT mice in Fig. 6 and the average fitted curve parameter values are provided in Table 2 . Although there was a trend for the $\mathrm{T}_{0}$ to be prolonged in the 5XFAD mice versus control mice $(64.1 \pm 25.8$ versus $39.2 \pm 28.8 \mathrm{~min})$, this difference was not significant. As with 12-monthold mice, the clearance of the CatD Targeted agent at $1 \mathrm{~h}\left(\lambda_{1 h r}\right)$ was significantly slower in 5XFAD mice compared to WT mice $\left(-0.62 \pm 0.08 \times 10^{-2} \mathrm{~min}^{-1}\right.$ versus $\left.-0.92 \pm 0.08 \times 10^{-2} \mathrm{~min}^{-1} ; p<0.05\right)$ as was the overall clearance rate $\left(\lambda_{\text {Total }}\right)(-1.02 \pm 0.06$ versus $\left.-1.25 \pm 0.03 \times 10^{-2} \mathrm{~min}^{-1} ; p<0.05\right)$. However, the Plateau Total, and $S I_{2 h r s}-S I_{1 h r s}$ were not different between groups. The AUC for the ROC was evaluated for $\lambda_{1 \mathrm{hr}}$ (null hypothesis: true area $=0.5$ ). For the 5month-old 5XFAD compared to WT mice, the AUC was significantly higher than the null hypothesis $(0.89$; $p=0.02$ ) for $\lambda_{1 \mathrm{hr}}$, demonstrating that this agent can successfully differentiate between WT and 5XFAD mice at 5 months of age.

\section{CatD expression}

CatD expression was examined in primary somatosensory cortex of WT and 5XFAD mice at 4 and 12 months of age using histology. Representative tissue sections are shown in Fig. 7. In these sections, CatD staining was visible intracellularly in WT mice at 4 months of age, and staining increased at 12 months of age. The 5XFAD mice also showed 
intracellular CatD staining at both time points (Fig. 7; arrow heads) but also demonstrated CatD staining in large extracellular deposits resembling amyloid plaques at both ages (Fig. 7; arrows). In these sections, there appeared to be an increase in CatD staining in 5XFAD mice compared to WT controls at both ages.

The expression of CatD in these sections was quantified by measuring the area covered by CatD immunostaining using ImageJ (Fig. 8). At 4 months of age, CatD staining covered $3.2 \pm 0.3 \%$ of the cortex in WT mice, and this increased to $16.2 \pm 1.2 \%$ in the 5XFAD mice $(p<0.01)$. Similarly, at 12 months of age, CatD staining covered $5.8 \pm 1.1 \%$ of the cortex in WT mice, which increased to $29.5 \pm 1.2 \%$ in the 5XFAD mice $(p<0.01)$. Staining was increased with age in the 5XFAD mice $(p<0.01)$ but not in WT controls. These results demonstrate that CatD expression is increased in 5XFAD mice, and that this difference increases with age.

\section{DISCUSSION}

Here, we characterize the behavior of a novel contrast agent targeting CatD for the diagnosis of $\mathrm{AD}$ in the 5XFAD Tg Alzheimer mouse model. The CA was composed of an MR/optical detection probe that incorporated a chelated lanthanide metal (Gd) and a NIR dye. The chelating DOTA structure allows clinically translatable tomographic imaging modalities to be pursued at a later time point (e.g., PET or MRI) without the need for any chemical structural changes [55]. The NIR dye was conjugated to a known and validated [54] enzymatic hydrolysis site for CatD and a cell penetrating Tat peptide. The Tat peptide allows the agent to permeate the BBB and enter the brain in a bidirectional fashion [48]. The Tat peptide has previously been shown to enter into the hippocampus and portions of the cortex (known sites of heightened AD pathology) with at least $0.2 \%$ of the intravenous dose taken up per gram of brain [48]. Once inside the brain, the cleavage at the CatD site removes the Tat peptide. This enables the diffusion of the Tat peptide out of the cell [54] while temporarily trapping the CA in the CNS compartment.

Comparing the uptake and washout between the 12month-old 5XFAD mice and WT controls, the CatD Targeted agent demonstrated clearly different uptake and washout kinetics, with a higher $\mathrm{SI}_{\max }$, a slower washout $\left(\lambda_{1 h r}, \lambda_{\text {Total }}\right.$, and $\left.S I_{1 h r}-S I_{2 h}\right)$ and a higher plateau. In the 5-month-old mice, the cell penetrating
CatD Targeted CA exhibited a significantly lower rate of clearance $\left(\lambda_{1 h r}, S I_{1 h r}-S I_{2 h r}\right)$ from the brain compared to age-matched WT control mice resulting in higher $\mathrm{CA}$ retention.

These results are consistent with our previous ex vivo examination [55] of the uptake and washout of a similar CatD Targeted CA in 12-month-old APP/PS1-dE9 (APP/PS1) mice. The previous study also demonstrated greater retention of the cell penetrating CatD Targeted agent in APP/PS1 mice compared to WT mice [55]. In the current study we were able to provide a more complete in vivo evaluation of the CA washout kinetics with the inclusion of Non-Targeted and NonPenetrating control agents. In the current study, no differences in CA washout between 5XFAD and WT animals were observed when using the control CAs, suggesting that both the Tat peptide and the CatD cleavage site were required for the uptake and specificity of the agent. Additional control experiments with use of inhibitors targeting CatD activity would have helped to prove the specificity of the cell penetrating CatD Targeted CA. But we are unaware of inhibitors that have the required kinetics and ability to cross through the BBB.

The 5XFAD mice also exhibited a significantly $(p<0.05)$ higher $S I_{\max }$ compared to the WT control mice following administration of the Non-Penetrating CA ( $35 \%$ higher signal in 5XFAD), Non-Targeted CA ( $\sim 64 \%$ higher signal in 5XFAD), and CatDTargeted CA $(\sim 55 \%$ higher signal in 5XFAD). The significantly higher $S I_{\max }$ of the 5XFAD compared to the WT mice coincided with a significant $26 \%$ lower body weight $(p<0.05)$. Since the CA dose remained at $5 \mathrm{nmol} /$ injection regardless of weight, the $S I_{\max }$ was likely higher in the 5XFAD mice as a result of an average $35 \%$ higher CA plasma concentration. The fact that the Targeted and Non-Targeted agents had $S I_{\text {max }}$ that averaged $64 \%$ and $55 \%$ higher, respectively, implies increased uptake of the agents, and not merely increased plasma concentration.

Another possible source of increased signal in the 5XFAD mice is the change in structure of the contrast agent itself after interaction with CatD. For example, the Non-Penetrating CA produced a higher emission intensity at a shorter wavelength compared to the CatD Targeted CA, while cleavage of the CatD Targeted CA by CatD produced an emission spectrum that was intermediate (Fig. 2A; red) as expected. The increased fluorescence of the cleaved agent compared to the intact CatD Targeted CA is likely due to quenching of the fluorophore by the longer amino acid peptide backbone in the CatD Targeted CA. As a result, enzy- 
matic cleavage of the $\mathrm{CA}$ could have contributed to the significant increase in fluorescence intensity in the 5XFAD mice compared to WT controls.

There are several limitations that must be considered in the current study. The first is that we did not asses the stability of the CA. However, the serum-based half-lives of the CPP and IRDye $800 \mathrm{CW}$ are $\sim 8.8 \mathrm{~h}$ [63] and $\sim 8$ days [63], respectively, so, it is unlikely that these components would degrade significantly in the 4-h post-injection window studied here. We must also consider the mouse models studied. Although 5XFAD mice only recapitulate some aspects of the pathology observed in humans, this study used the 5XFAD because this model is known to have higher levels of CatD compared to controls [42, 43], as is the case in humans $[32,34]$. Whether CatD overexpression precedes amyloid pathology in 5XFAD mice similar to human AD pathology [33] has yet to be shown; however, it is not a necessity for the preliminary investigation of our CA. In addition, we used WT $\mathrm{C} 57 \mathrm{Bl} / 6$ mice as the control group. Non-Tg littermates would be preferred as they are a better genetic match to the experimental group, and further studies comparing Tg to non-Tg littermates are ongoing. Moreover, although cerebral perfusion and vascular permeability were not measured in these animals, the lack of a significant difference in the washout kinetics of the Non-Targeted and Non-Penetrating CAs between WT and 5XFAD mice suggests that these factors were not significantly different between these groups. Finally, due to the nature of the non-tomographic optical imaging used, the exact contribution of the CA accumulated within the brain, skull, vasculature, and skin to the detected signal is unknown. However, there were no significant differences in the skin signal kinetics between the 5XFAD and WT animals when using the CatD targeted CA, no significant differences between the 5XFAD and WT animals when using the control CAs, and CatD overexpression in the brain of 5XFAD mice was validated. Therefore, we believe that the significant differences in observed signal kinetics between the 5XFAD and WT animals are pre dominantly the result of preferential brain uptake in the 5XFAD mice. Future utilization of tomographic imaging techniques will provide further insight in to the brain-specific accumulation of the CA compared to other tissues.

The major strengths of this study are the use of the engineered control CAs and the use of a NIR dye. The use of agents lacking a CPP or CatD cleavage site demonstrate that the uptake and retention of the CA are not non-specific, and depend on the CPP and the CatD cleavage. Although complicated light scattering of the NIR signal reduces resolution compared to Oregon Green fluorescence in our previous work, the NIR signal provides much higher signal-tobackground contrast, and reduced auto-fluorescence. Furthermore, because NIR light can penetrate tissues for up to several centimeters, it allows imaging of the agents in live animals.

In conclusion, we have developed a contrast agent that targets CatD and shows promise as a tool for the diagnosis of AD. Specifically, the measured $\lambda_{1 h r}$ as well as $\lambda_{\text {Total }}$ with its associated Plateau $u_{\text {Total }}$ following administration of the cell-penetrating CatD Targeted CA may be used to differentiate between AD model mice and WT controls at 5 months and 12 months of age. At 12 months of age, $S I_{1 h r}-S I_{2 h r}$ and Plateau Total may also be used to differentiate between AD and WT mouse models. This study is the first to provide proof of principle for in vivo detection of $\mathrm{AD}$ in an animal model with CatD overexpression, a unique yet validated human pathology associated with $\mathrm{AD}$. Future studies will examine CatD expression over the lifespan of several animal models and correlate these findings with the development of AD pathology.

\section{ACKNOWLEDGMENTS}

The authors gratefully acknowledge student stipend support donated by William Shipman and from the Alzheimer Society of London and Middlesex, the Queen Elizabeth II Graduate Scholarships in Science and Technology, and the Ontario Graduate Scholarships. Additionally, the authors express much gratitude to the Lawson Health Research Institute optical imaging lab, Jennifer Hadway and Lise Desjardins (both RVT, RLAT-R) for their experimental and animal handling support, Dr. Mamadou Diop for hardware technical support, and finally Zengxaun Nong and Caroline O'Neil for histology and staining expertise. Additionally, funding for this study was provided by the Canadian Institutes of Health Research (MOP106535).

Authors' disclosures available online (http://jalz.com/manuscript-disclosures/15-0123r1).

\section{REFERENCES}

[1] Alzheimer's Association (2014) 2014 Alzheimer's disease facts and figures. Alzheimers Dement 10, e47-e92.

[2] Perl DP (2010) Neuropathology of Alzheimer's disease. Mt Sinai J Med 77, 32-42. 
[3] Terry RD, Masliah E, Salmon DP, Butters N, DeTeresa R, Hill R, Hansen LA, Katzman R (1991) Physical basis of cognitive alterations in Alzheimer's disease: Synapse loss is the major correlate of cognitive impairment. Ann Neurol 30, 572-580.

[4] Maruszak A, Zekanowski C (2011) Mitochondrial dysfunction and Alzheimer's disease. Prog Neuropsychopharmacol Biol Psychiatry 35, 320-330.

[5] Zlokovic BV (2011) Neurovascular pathways to neurodegeneration in Alzheimer's disease and other disorders. Nat Rev Neurosci 12, 723-738.

[6] Storkebaum E, Quaegebeur A, Vikkula M, Carmeliet P (2011) Cerebrovascular disorders: Molecular insights and therapeutic opportunities. Nat Neurosci 14, 1390-1397.

[7] Cummings J, Zhong K (2014) Biomarker-driven therapeutic management of Alzheimer's disease: Establishing the foundations. Clin Pharmacol Ther 95, 67-77.

[8] Coley N, Andrieu S, Delrieu J, Voisin T, Vellas B (2009) Biomarkers in Alzheimer's disease: Not yet surrogate endpoints. Ann N Acad Sci 1180, 119-124.

[9] Schneider LS, Mangialasche F, Andreasen N, Feldman H, Giacobini E, Jones R, Mantua V, Mecocci P, Pani L, Winblad B, Kivipelto M (2014) Clinical trials and late-stage drug development for Alzheimer's disease: An appraisal from 1984 to 2014. J Intern Med 275, 251-283.

[10] Cummings JL, Morstorf T, Zhong K (2014) Alzheimer's disease drug-development pipeline: Few candidates, frequent failures. Alzheimers Res Ther 6, 37.

[11] Berk C, Sabbagh MN (2013) Successes and failures for drugs in late-stage development for Alzheimer's disease. Drugs Aging 30, 783-792.

[12] Carlson NE, Moore MM, Dame A, Howieson D, Silbert LC, Quinn JF, Kaye JA (2008) Trajectories of brain loss in aging and the development of cognitive impairment. Neurology $\mathbf{7 0}$, 828-883.

[13] Johnson NA, Jahng GH, Weiner MW, Miller BL, Chui HC, Jagust WJ, Gorno-Tempini ML, Schuff N (2005) Pattern of cerebral hypoperfusion in Alzheimer disease and mild cognitive impairment measured with arterial spin-labeling MR imaging: Initial experience. Radiology 234, 851-859.

[14] Borroni B, Anchisi D, Paghera B, Vicini B, Kerrouche N, Garibotto V, Terzi A, Vignolo LA, Di Luca M, Giubbini R, Padovani A, Perani D (2006) Combined 99mTc-ECD SPECT and neuropsychological studies in MCI for the assessment of conversion to AD. Neurobiol Aging 27, 24-31.

[15] Dickerson BC, Sperling RA (2008) Functional abnormalities of the medial temporal lobe memory system in mild cognitive impairment and Alzheimer's disease: Insights from functional MRI studies. Neuropsychologia 46, 1624-1635.

[16] Chetelat G, Landeau B, Eustache F, Mezenge F, Viader F, de la Sayette V, Desgranges B, Baron JC (2005) Using voxelbased morphometry to map the structural changes associated with rapid conversion in MCI: A longitudinal MRI study. Neuroimage 27, 934-946.

[17] Moulin CJ, Laine M, Rinne JO, Kaasinen V, Sipila H, Hiltunen J, Kangasmaki A (2007) Brain function during multi-trial learning in mild cognitive impairment: A PET activation study. Brain Res 1136, 132-141.

[18] Mathis CA, Wang Y, Holt DP, Huang GF, Debnath ML, Klunk WE (2003) Synthesis and evaluation of 11C-labeled 6substituted 2-arylbenzothiazoles as amyloid imaging agents. J Med Chem 46, 2740-2754.

[19] Archer HA, Edison P, Brooks DJ, Barnes J, Frost C, Yeatman T, Fox NC, Rossor MN (2006) Amyloid load and cerebral atrophy in Alzheimer's disease: An 11C-PiB positron emission tomography study. Ann Neurol 60, 145-147.

[20] Klunk WE, Engler H, Nordberg A, Wang Y, Blomqvist G, Holt DP, Bergstrom M, Savitcheva I, Huang GF, Estrada S, Ausen B, Debnath ML, Barletta J, Price JC, Sandell J, Lopresti BJ, Wall A, Koivisto P, Antoni G, Mathis CA, Langstrom B (2004) Imaging brain amyloid in Alzheimer's disease with Pittsburgh Compound-B. Ann Neurol 55, 306-319.

[21] Forsberg A, Engler H, Almkvist O, Blomquist G, Hagman G, Wall A, Ringheim A, Langstrom B, Nordberg A (2008) PET imaging of amyloid deposition in patients with mild cognitive impairment. Neurobiol Aging 29, 1456-1465.

[22] Jack J C R, Lowe VJ, Senjem ML, Weigand SD, Kemp BJ, Shiung MM, Knopman DS, Boeve BF, Klunk WE, Mathis CA, Petersen RC (2008) 11C PiB and structural MRI provide complementary information in imaging of Alzheimer's disease and amnestic mild cognitive impairment. Brain 131, 665-680.

[23] Okamura N, Harada R, Furumoto S, Arai H, Yanai K, Kudo Y (2014) Tau PET imaging in Alzheimer's disease. Curr Neurol Neurosci Rep 14, 500.

[24] Zimmer ER, Leuzy A, Bhat V, Gauthier S, Rosa-Neto P (2014) In vivo tracking of tau pathology using positron emission tomography (PET) molecular imaging in small animals. Transl Neurodegener 3, 6.

[25] Fawaz MV, Brooks AF, Rodnick ME, Carpenter GM, Shao X, Desmond TJ, Sherman P, Quesada CA, Hockley BG, Kilbourn MR, Albin RL, Frey KA, Scott PJ (2014) High affinity radiopharmaceuticals based upon lansoprazole for PET imaging of aggregated tau in Alzheimer's disease and progressive supranuclear palsy: Synthesis, preclinical evaluation, and lead selection. ACS Chem Neurosci 5, 718-730.

[26] Tago T, Furumoto S, Okamura N, Harada R, Ishikawa Y, Arai H, Yanai K, Iwata R, Kudo Y (2014) Synthesis and preliminary evaluation of 2-arylhydroxyquinoline derivatives for tau imaging. J Label. Comp Radiopharm 57, 18-24.

[27] Ossenkoppele R, Schonhaut DR, Baker SL, O’Neil JP, Janabi M, Ghosh PM, Santos M, Miller ZA, Bettcher BM, GornoTempini ML, Miller BL, Jagust WJ, Rabinovici GD (2015) Tau, amyloid, and hypometabolism in a patient with posterior cortical atrophy. Ann Neurol 77, 338-342.

[28] Chien DT, Szardenings AK, Bahri S, Walsh JC, Mu F, Xia C, Shankle WR, Lerner AJ, Su MY, Elizarov A, Kolb HC (2014) Early clinical PET imaging results with the novel PHF-tau radioligand [F18]-T808. J Alzheimers Dis 38, 171-184.

[29] Aizenstein HJ, Nebes RD, Saxton JA, Price JC, Mathis CA, Tsopelas ND, Ziolko SK, James JA, Snitz BE, Houck PR, Bi W, Cohen AD, Lopresti BJ, DeKosky ST, Halligan EM, Klunk WE (2008) Frequent amyloid deposition without significant cognitive impairment among the elderly. Arch Neurol 65, 1509-1517.

[30] Bateman RJ, Xiong C, Benzinger TL, Fagan AM, Goate A, Fox NC, Marcus DS, Cairns NJ, Xie X, Blazey TM, Holtzman DM, Santacruz A, Buckles V, Oliver A, Moulder K, Aisen PS, Ghetti B, Klunk WE, McDade E, Martins RN, Masters CL, Mayeux R, Ringman JM, Rossor MN, Schofield PR, Sperling RA, Salloway S, Morris JC (2012) Clinical and biomarker changes in dominantly inherited Alzheimer's disease. $N$ Engl J Med 367, 795-804.

[31] Benes P, Vetvicka V, Fusek M (2008) Cathepsin D-many functions of one aspartic protease. Crit Rev Oncol Hematol 68, 12-28

[32] Cataldo AM, Paskevich PA, Kominami E, Nixon RA (1991) Lysosomal hydrolases of different classes are abnormally 
distributed in brains of patients with Alzheimer disease. Proc Natl Acad Sci U S A 88, 10998-11002.

[33] Cataldo AM, Barnett JL, Berman SA, Li J, Quarless S, Bursztajn S, Lippa C, Nixon RA (1995) Gene expression and cellular content of cathepsin D in Alzheimer's disease brain: Evidence for early up-regulation of the endosomal-lysosomal system. Neuron 14, 671-680.

[34] Schwagerl AL, Mohan PS, Cataldo AM, Vonsattel JP, Kowall NW, Nixon RA (1995) Elevated levels of the endosomallysosomal proteinase cathepsin D in cerebrospinal fluid in Alzheimer disease. J Neurochem 64, 443-446.

[35] De-Paula VJ, Radanovic M, Diniz BS, Forlenza OV (2012) Alzheimer's disease. Subcell Biochem 65, 329-352.

[36] Strome EM, Doudet DJ (2007) Animal models of neurodegenerative disease: Insights from in vivo imaging studies. $\mathrm{Mol}$ Imaging Biol 9, 186-195.

[37] Meguro K, Blaizot X, Kondoh Y, Le Mestric C, Baron JC, Chavoix C (1999) Neocortical and hippocampal glucose hypometabolism following neurotoxic lesions of the entorhinal and perirhinal cortices in the non-human primate as shown by PET. Implications for Alzheimer's disease. Brain $\mathbf{1 2 2}$ (Pt 8), 1519-1531.

[38] Millien I, Blaizot X, Giffard C, Mezenge F, Insausti R, Baron JC, Chavoix C (2002) Brain glucose hypometabolism after perirhinal lesions in baboons: Implications for Alzheimer disease and aging. J Cereb Blood Flow Metab 22, 1248-1261.

[39] Bhagat YA, Obenaus A, Richardson JS, Kendall EJ (2002) Evolution of beta-amyloid induced neuropathology: Magnetic resonance imaging and anatomical comparisons in the rodent hippocampus. MAGMA 14, 223-232.

[40] Oakley H, Cole SL, Logan S, Maus E, Shao P, Craft J, Guillozet-Bongaarts A, Ohno M, Disterhoft J, Van Eldik L, Berry R, Vassar R (2006) Intraneuronal beta-amyloid aggregates, neurodegeneration, and neuron loss in transgenic mice with five familial Alzheimer's disease mutations: Potential factors in amyloid plaque formation. $J$ Neurosci $\mathbf{2 6}$, 10129-10140.

[41] Kimura R, Ohno M (2009) Impairments in remote memory stabilization precede hippocampal synaptic and cognitive failures in 5XFAD Alzheimer mouse model. Neurobiol Dis $\mathbf{3 3}$, 229-235.

[42] Youmans KL, Tai LM, Kanekiyo T, Stine J, Michon WB, Nwabuisi-Heath SC, Manelli E, Fu AM, Riordan Y, Eimer S, Binder WA, Bu L, Yu G, Hartley C, LaDu DM, MJ (2012) Intraneuronal Abeta detection in 5xFAD mice by a new Abetaspecific antibody. Mol Neurodegener 7, 8 .

[43] Amritraj A, Hawkes C, Phinney AL, Mount HT, Scott CD, Westaway D, Kar S (2009) Altered levels and distribution of IGF-II/M6P receptor and lysosomal enzymes in mutant APP and APP+PS1 transgenic mouse brains. Neurobiol Aging 30 54-70.

[44] Oldendorf WH (1971) Brain uptake of radiolabeled amino acids, amines, and hexoses after arterial injection. Am J Physiol 221, 1629-1639.

[45] Oldendorf WH (1974) Lipid solubility and drug penetration of the blood brain barrier. Proc Soc Exp Biol Med 147 813-815.

[46] Penichet ML, Kang YS, Pardridge WM, Morrison SL, Shin SU (1999) An antibody-avidin fusion protein specific for the transferrin receptor serves as a delivery vehicle for effective brain targeting: Initial applications in anti-HIV antisense drug delivery to the brain. J Immunol 163, 4421-4426.
[47] Banks WA (2009) Characteristics of compounds that cross the blood-brain barrier. BMC Neurol 9 Suppl 1, S3.

[48] Banks WA, Robinson SM, Nath A (2005) Permeability of the blood-brain barrier to HIV-1 Tat. Exp Neurol 193, 218-227.

[49] Temsamani J, Vidal P (2004) The use of cell-penetrating peptides for drug delivery. Drug Discov Today 9, 1012-1019.

[50] Maxwell D, Chang Q, Zhang X, Barnett EM, Piwnica-Worms D (2009) An improved cell-penetrating, caspase-activatable, near-infrared fluorescent peptide for apoptosis imaging. Bioconjug Chem 20, 702-709.

[51] Madani F, Lindberg S, Langel U, Futaki S, Graslund A (2011) Mechanisms of cellular uptake of cell-penetrating peptides. J Biophy 2011, 414729.

[52] Richard JP, Melikov K, Vives E, Ramos C, Verbeure B, Gait MJ, Chernomordik LV, Lebleu B (2003) Cell-penetrating peptides. A reevaluation of the mechanism of cellular uptake. J Biol Chem 278, 585-590.

[53] Mishra R, Su W, Pohmann R, Pfeuffer J, Sauer MG, Ugurbil K, Engelmann J (2009) Cell-penetrating peptides and peptide nucleic acid-coupled MRI contrast agents: Evaluation of cellular delivery and target binding. Bioconjug Chem 20, 1860-1868.

[54] Suchy M, Ta R, Li AX, Wojciechowski F, Pasternak SH, Bartha R, Hudson RH (2010) A paramagnetic chemical exchange-based MRI probe metabolized by cathepsin D: Design, synthesis and cellular uptake studies. Org Biomol Chem 8, 2560-2566.

[55] Ta R, Suchy M, Tam JH, Li AX, Martinez-Santiesteban FS, Scholl TJ, Hudson RH, Bartha R, Pasternak SH (2013) A dual magnetic resonance imaging/fluorescent contrast agent for Cathepsin-D detection. Contrast Media Mol Imaging 8 , 127-139.

[56] Kovar JL, Simpson MA, Schutz-Geschwender A, Olive DM (2007) A systematic approach to the development of fluorescent contrast agents for optical imaging of mouse cancer models. Anal Biochem 367, 1-12.

[57] Robinson HA, Kwon S, Hall MA, Rasmussen JC, Aldrich MB, Sevick-Muraca EM (2013) Non-invasive optical imaging of the lymphatic vasculature of a mouse. J Vis Exp, e4326.

[58] Sampath L, Wang W, Sevick-Muraca EM (2008) Near infrared fluorescent optical imaging for nodal staging. J Biomed Opt 13, 041312

[59] Marshall MV, Draney D, Sevick-Muraca EM, Olive DM. (2010) Single-dose intravenous toxicity study of IRDye $800 \mathrm{CW}$ in Sprague-Dawley rats. Mol Imaging Biol 12, 583-594.

[60] Kovar JL, Xu X, Draney D, Cupp A, Simpson MA, Olive DM (2011) Near-infrared-labeled tetracycline derivative is an effective marker of bone deposition in mice. Anal Biochem 416, 167-173.

[61] Coin I, Beyermann M, Bienert M (2007) Solid-phase peptide synthesis: From standard procedures to the synthesis of difficult sequences. Nat Protoc 2, 3247-3256.

[62] Sarko D, Beijer B, Garcia Boy R, Nothelfer EM, Leotta K, Eisenhut M, Altmann A, Haberkorn U, Mier W (2010) The pharmacokinetics of cell-penetrating peptides. Mol Pharm 7, 2224-2231.

[63] Sampath L, Kwon S, Ke S, Wang W, Schiff R, Mawad ME, Sevick-Muraca EM (2007) Dual-labeled trastuzumab-based imaging agent for the detection of human epidermal growth factor receptor 2 overexpression in breast cancer. J Nucl Med 48, 1501-1510. 